\title{
Building Enduring Peace in Northeast Asia: Overcoming Perceptional and Positional Obstacles
}

\author{
Brendan M. Howe
}

\begin{abstract}
The processes of making foreign policy decisions and forming assumptions about the nature of the "other" comprise major challenges to the transformation of conflictual relationships and construction of an enduring peace in Northeast Asia. In this article, in order to make progress towards these goals, methodologies for unpacking the "black box of decision," understanding the "other," deconstructing the relationship between positions and interests, and increasing the role played by non-state and substate actors are explored. The paper first assesses theoretical and practical tools used for addressing the problems. It then considers other conflictual relationships that have faced similar obstacles, and the processes which were employed in an attempt to ameliorate them. It concludes with a policy prescription for breaking the vicious cycle of hurt, blame, and rising nationalism in the region.
\end{abstract}

Keywords conflict transformation, reconciliation, partisan perceptions, positions and interests, public diplomacy, non-state centricity

\section{Introduction}

Many long-running conflicts or post-conflict legacies give the appearance of being intractable for two reasons: first, rather than there being an objective historical truth about the conflict waiting to be uncovered, there are in fact competing perceptions and regimes of truth each held as sacrosanct by the different actors; second, actors have become so wedded to particular conflictual positions and roles, they are blinded to the shared interest in reconciliation and the benefits this entails. Certainly these conditions hold true for the conflictual relations between the countries of Northeast Asia. Yet such conflicts are not necessarily, intractable, and transformation of conflictual relationships, while difficult, is both possible and empirically demonstrable. This paper examines theoretical prescriptions and case studies where theory has been put into practice, in order to draw lessons for 
addressing the challenges of transforming conflictual relationships in Northeast Asia. The focus is on policy prescription for steps which may be taken to break the vicious cycle of hurt, blame, and rising nationalism in the region.

One of the main challenges to transforming conflictual relationships in Northeast Asia is the enduring universal self-imaging of victimhood, and the apportioning of blame to other agencies. Indeed, all countries in the region have recent histories of massive human rights abuses by their own authorities, but also as a result of the actions of external agencies. Both Chinas, the People's Republic of China (PRC) and the Republic of China (ROC), and both Koreas, the Republic of Korea (ROK) and the People's Democratic Republic of Korea (DPRK), count themselves as victims of Japanese imperialism, aggression, and massive human rights abuses. These self-perceptions are also part of a larger and longer historical discourse on colonization endured by these countries. Japan's self-perception, on the other hand, is of an Asian champion standing up for the region and liberating other countries from European domination, for which it was punished in the most horrific way, not only with the atomic bombing of Hiroshima and Nagasaki, but also the firebombing of Tokyo, the annexation of Japan's most northerly territories by Russia and the occupation of Japan by the United States. Japan feels further threatened by the rising military power and assertiveness of both the PRC and the DPRK. Furthermore, conflictual conditions are being exacerbated across the board by rising nationalism among the younger generations. Young people in Japan feel less responsible for the sins of their increasingly distant forefathers, while young people in China and Korea champion a new confidence and assertiveness on the international stage.

How then can these conflictual positions and contradictory perceptions be reconciled? First, we must understand the processes of position taking and perception formation. Thus this paper starts with the theoretical analysis of two independent causal variables: the process of foreign policy making and forming assumptions about the nature of the other, and how they contribute to the dependent variable of a conflictual relationship. Second, we must look to how these processes may be deconstructed in order to bring to the fore the concept of a harmony of interests and transformation of conflictual relationships. Thus the pioneering work of the Harvard Negotiation Project and John Burton is highlighted in the second analytical section. Third, we must look to practical examples where such reconciliation appears to have borne fruit, or holds the promise of bearing fruit. Finally, this paper presents policy prescription for breaking the conflictual cycle and constructing an enduring peace in Northeast Asia. 


\section{Decisions, Positions, Perceptions, and Misperceptions}

The processes of foreign policy decision making and forming assumptions about the nature of the "other" pose major challenges to reconciliation in Northeast Asia. The region remains a decidedly state-centric security operating environment, resistant to international concepts and norms revolving around universalism, solidarism, collective security, as well as human rights and human security and "is one of few areas in the world where most countries strongly defend traditional concepts of national sovereignty and firmly resist foreign intervention in the internal affairs of independent states" (Chu 2001, 1). In part, as a result of experiences of colonialism, "the collective autonomy and dignity of the state from foreign domination takes precedence over autonomy and dignity of the individual which lies at the core of human security" with Asian states remaining among the most ardent champions of Westphalian sovereignty (Acharya 2003, 9). As a result, international relations in the region remain adversarial and resistant to the generation of trust, a prerequisite to reconciliation and the transformation of conflictual relationships. Decision making tends to take place at the state level and in accordance with the defense of state-level positions and interests. Furthermore, there is a general perception of the "other" as necessarily adopting similar processes.

It is from this starting point that Graham Allison begins his classic work, Essence of Decision. His first model of decision making, the rational actor model, adopts the view of the state as unitary rational actor; that is to say, a single indivisible entity (similar to an individual human being) that makes choices on the basis of rational application of cost/benefit analysis with regard to a hierarchy of values and preferred outcomes. These choices are used in order to promote solutions to strategic problems with regard to maximizing utility, minimizing cost and achieving strategic goals. This leads to a "conception of international politics as 'essentially bargaining situations' in which alert, intelligent, coordinated nations speak and move in order to influence other nations by changing their expected payoffs" (Allison 1971, 22).

The influence of individual preferences, perceptions and morality is supposedly minimized by emphasizing the importance of the state as actor within this concept. If statesmen are rational and act in accordance with the needs of the society and national interest, then no matter who is at the helm, the ship will be steered in the same direction. Rational decision makers are expected to construct a hierarchy of preferred outcomes and then conduct a simple costbenefit analysis (in terms of national interest and resources) in order to determine which course of action to take. Because the output of decision making impacts on others, and their output becomes input for one's own decision making, the operating environment can be described as strategic. Hence, the complexities of the decision-making process are simplified through the concept of a "black box of 
decision."

States do not, however, make decisions. Rather, statesmen at the head of states, or at the head of the constitutive bureaucratic elements that comprise the apparatus of the state, formulate policy on behalf of the state, and take up positions to represent the state, interpreting the interests of the state as best they can. Under such circumstances the perceptions of the decision-maker, far from being an irrelevance, are in fact key to the direction policy will ultimately take. In addition, decision makers are subject to internal pushes and pulls that may weight policy in what would appear to international observers to be an irrational direction.

The different perception filters through which actors view the world have considerable bearing not only upon how they reach their "rational" decisions, but even upon the processing of information upon which they will construct their preference hierarchies. At the national or societal level, perceptions are based on shared experiences and images, received wisdom, national historical projects and discourse, and social construction of truth. Perception affects decision-making rationality through self-imaging and what has become known as "perception of the other." Consistency in policy can therefore be seen as a result of the strong tendency for people to see what they expect to see and to assimilate incoming information to fit pre-existing images formed through national, organizational, and personal experience, as well as through planning and standard operating procedures (Jervis 1976, 117). Indeed, actors' theories and images play a large part in determining what they notice. "In other words actors tend to perceive what they expect" (Jervis 1969, 240).

People tend to adopt the first image of their adversary that seems to fit the adversary's actions, and are very reluctant to subsequently change this perception. This may not be an instinctive "first impression," but may be the result of a "rational" decision. If the actor believes that their first, tentative guesses will soon be corrected if they are wrong and can be of assistance if they are right, they will not hesitate to make them. Unfortunately, the assumption that wrong guesses will soon be rectified is erroneous. Actors will continue a fair way down a blind alley before they realize that their basic assumption needs revision. This is due to the fact that they will ignore information that does not fit, twist it so that it confirms, or at least does not contradict their beliefs, and deny its validity, while "confirming evidence, by contrast, is quickly and accurately noted" (Jervis 1976, 143). Thomas Kuhn (1962, 23-24) noted similar processes at play when addressing the difficulty of achieving a paradigm shift in scientific understanding, in that the orthodox community will "attempt to force nature into the preformed and relatively inflexible box" that the existing paradigm supplies, while new phenomena that do not fit into the box will often not be seen at all.

A number of general points can be made with regard to the impact of prejudicial, stereotypical, biased, or "partisan" perceptions upon decision making 
in international negotiations. First, it is likely that the more uncertainty that surrounds the information upon which decision makers are formulating policy, the greater the impact of pre-existing theories and images upon interpretation of the data. If messages are sent from a different background of concerns and information than is possessed by the receiver, misunderstanding is more likely due to cultural, political, social, linguistic, historical, and cognitive dissonance. Second, the surer a decision maker is about the validity of their pre-existing theories and images, the greater the impact upon interpretation of the data. Third, the more effort has been expended by the decision maker in the construction of their pre-existing theories and images, the more likely they are to be "entrapped" by these "sunk costs," and therefore the more resistant they are likely to be to new ideas or images. Sunk costs are the costs which have been expended, whether material resources or human effort, in constructing the current position, and which have a hold over the decision maker by virtue of their going to waste if the position is abandoned.

Indeed, sunk costs, entrapment and pre-existing policy decisions can essentially negate the rational decision-making process entirely. Models of nondecision describe a situation wherein policy is only created through a process of "disjointed incrementalism" (i.e., small undirected steps), and that rather than decision making or decisive policy change, for the vast majority of the time "incremental drift," or slight modifications of existing policy, is the norm (Baybrooke and Lindblom 1969, 223). Hence Herbert Simon $(1991,125)$ refers to "bounded rationality" wherein rather than being open to all rational alternatives, "what an individual learns in an organization is very much dependent on what is already known to (or believed by) other members of the organization." Simon also introduced the concept of "satificing" (a combination of satisfying and sufficing), whereby any needle in the haystack is accepted rather than continuing to search for the sharpest, or the first, image which seems to fit the available data (Simon 1956, 129; 1957).

As a result of partisan perceptions, actors tend to overlook the fact that evidence consistent with their theories may also be consistent with other views or explanations for the actions of others. They also tend to overlook the fact that more than one interpretation or explanation can be placed upon their own actions. Actors tend to see others as more hostile than they are, and to interpret the signals of others in a more negative way than they were likely intended. We are familiar in all forms of international negotiation with the tendency towards "worst case" analysis, where it is considered rational to assume and prepare for the worst. If the effect of another's action is to injure or threaten the actor, the actor is apt to believe that such was the other's purpose and intent. On the other hand, actors tend to see their own actions and signals in the best possible light and are confused or hurt when others do not share this perception.

Ironically, international actors often perceive their negotiating partners as 
more unitary and rational than they actually are. While actors are often very aware of their own internal political games, nevertheless they have a tendency to perceive the behavior of others (especially in the international environment) as more centralized, disciplined, and coordinated, and therefore more rational (in unitary rational actor terms) than is actually the case. Because a state gets most of its information about the other state's policies from the other's foreign office, it tends to take the foreign office's position for the stand of the government as a whole, or worse, as representing the will of the society as a whole. In East Asia, in particular, history textbooks have had a similar impact: no matter how limited their distribution they are seen to represent the societal consensus, whereas they actually involve state-centric impositions, or minority perspectives.

Thus in order to make progress towards reconciliation, it is important to unpack the "black box of decision," attempt understanding of the "other," deconstruct the relationship between positions and interests, and increase the role played by non-state and sub-state actors. The next section attempts to go some way towards addressing these concerns by suggesting theoretical remedies for the practical challenges of securing a lasting peace in Northeast Asia.

\section{Dealing with Positional and Perceptional Challenges}

Negotiating partners, and those who analyze negations, must come to the realization that an actor's interests are not necessarily the same as the positions they take (Fisher, Ury, and Patton 1991, 40-55). Positions are an actor's demands, list of wants, or a description of where the actor stands on an issue. Underlying these positions are the reasons parties demand something: their needs, concerns, desires, hopes and fears. A negotiated agreement or reconciliation that satisfies the interests of all parties has a good chance of lasting success, and is also achievable, even when parties take apparently irreconcilable positions. Furthermore, we need to take into account that "where you stand depends on where you sit." This maxim points to the importance of understanding an actors official position and background in order to predict where they may stand on a certain issue, and what might constitute the interests they are trying to fulfill.

Robert Putnam (1988) first articulated the theory that international agreements are the product of negotiations at both the internal domestic and external international level: a "two level game.” Likewise Graham Allison's second model of decision making, the "organizational process model," depicts policy as the product of "large semi-feudal, loosely allied organizations" (Allison 1971, 67). Allison presents the "bureaucratic politics model," or model three, as a second alternative to the rational actor model. In this model bureaucrats and governmental players bargain with each other to define what is the national interest and the best way for the national interest to be fulfilled. The motivations 
for individual players are shaped by triple-tiered hierarchies of preferences: by their own conceptions of what is the public good or the national interest, by their own organizational affiliation and its needs and interests, and by personal interests and career ambitions. Thus, foreign policy decisions are the result of negotiations among skilled policy-making practitioners and the outcome of internal political machinations (ibid., 146).

Karl Deutsch refers to a simple cascade model of national decision making consisting of five levels, each level a distinct reservoir of public or elite opinion and each reservoir linked to a particular complex of social institutions and status groups. The first of these is the social and economic elite, which does not form a simple monolithic group, but rather is connected by a dense net of multiple ties, links, and channels of communication. The second is the political and governmental elite, which is also not monolithic. Third we have the media of mass communication, fourth the network of local opinion leaders, and fifth the politically relevant strata of the population at large. Streams of information move downward in cascade fashion, from higher-level communications systems to lower-level ones. Each of the five groups, however, has its own memories and its own measure of autonomy. Each can reject, ignore, or reinterpret unpalatable messages. Each is capable of innovation and initiative. And each can also feed back a stream of information upward to some or all of the higher-level groups (Deutsch 1978, 119-122). When combined with the external operating environment examined through a relationship mapping exercise of all the players involved in the game, these streams of information help explain why leaders might feel the need to act in ways contrary to those dictated by a simple costbenefit analysis of their positions.

Understanding where your own interests truly lie will help establish what you really want from a negotiation, and may help you get what you need. In addition, however, one must uncover the interests which lie behind the positions taken by other actors. First and foremost, most simply put, we need to try to look at the negotiation or conflict from the other person's perspective. This does not mean agreeing, ultimately, with their position, but it does mean that we should make every effort to understand it. We are trying to comprehend, rather than to "buy into," their reasoning by placing ourselves in their shoes, or in their seat, and thereby gain an insight into their mind-set.

Engaging in such a process can, in actual fact, be extremely beneficial to our own position. The more we learn about others' concerns, the more likely we are to consider elements that had previously escaped our notice, the more likely we are to change our own minds, and the more likely we are to revise our thinking. Rethinking our policy may well be a benefit rather than a cost of understanding an adversary's point of view. With greater knowledge we might reduce the area of conflict and increase the chance of advancing our newly enlightened selfinterest. We might also discard policies that are doomed to fail, or encounter 
such resistance from the other that they become irrational (although we did not know this to be the case before we increased our strategic comprehension) before becoming entrapped through sunk costs. Indeed, Kal Holsti $(1991,158)$ informs us that "the more intense the interaction between the parties, the more important it is to incorporate perceptional data into the analysis."

Theorists such as Roger Fisher (1991; 1997) and John Burton (1969; 1990a; 1990b) have tried to formalize and model this process. The first step is to assess our own assumptions about the negotiation or conflict, and the data upon which we base them (sometimes called "assessing the first position"). Next, it is important to "assess the second position": consider what the other parties see (their partisan perceptions), why they see it that way (their background, emotions and motives), and the interests which lie behind their positions (Fisher et al. $1997,48-51)$. Both of these forms of assessment are carried out through a process of "cognitive mapping." We address our cognitive maps and infer those of other parties by studying assertions and causal beliefs. Why do we perceive the actions of others in a particular way, and, given our understanding of what they believe, or state they believe, how are they likely to perceive these actions of ours? In other words, what are our assumptions, why do we make them, is there any evidence that does not support our assumptions, and are there alternative explanations for our perceived reality which may fit the available data equally well or even better? This has been modeled by the Assumptions/Data Tool shown in Figure 1.

Figure 1. The Assumptions/Data Tool

\begin{tabular}{|c|c|}
\hline \multicolumn{1}{|c|}{ A. Assumptions } & \multicolumn{1}{c|}{ B. Base Data } \\
$\begin{array}{l}\text { What are the core assumptions about the } \\
\text { conflict? }\end{array}$ & $\begin{array}{l}\text { On what data have the assumptions been } \\
\text { based? }\end{array}$ \\
\hline \multicolumn{1}{|c|}{ D. Alternative Assumptions } & \multicolumn{1}{|c|}{ C. Nonconforming Data } \\
$\begin{array}{l}\text { Taking the additional data into account, what } \\
\text { might be some alternative conclusions about } \\
\text { the conflict? }\end{array}$ & $\begin{array}{l}\text { What additional data might be taken into } \\
\text { account that may be inconsistent with the } \\
\text { core assumptions? }\end{array}$ \\
\hline
\end{tabular}

Source: adapted from Fisher et al. 1997, 49.

The third step is to interact with the other parties in order to test our understanding of their positions. For Fisher and his associates at the Harvard Negotiation Project, this has tended to take the form of role-play workshops through which parties are engaged directly or indirectly in negotiations. Communication forms the core of the Harvard approach. Parties engage in "active listening" whereby the positions and underlying interests of other actors are directly solicited. Communication also forms the bedrock of improved 
relationships, which for Fisher et al. (1997) is an important strategic objective in its own right, independent of the pursuit of each actor's individual interest satisfaction.

For followers of John Burton, the process has tended to involve a problemsolving workshop to which all parties with the capacity to affect the outcome of negotiations are invited, where their common problems are jointly addressed as collective action rather than adversarial zero-sum negotiations. These parties will have been identified through the construction of a relationship map as detailed above. This inclusive approach means including non-state actors as participants. It also uses non-state actors in key organizational roles due to their non-confrontational and non-zero-sum positioning. For instance, the workshop is often organized and held by academics in a university seminar setting. In the workshop each party must explain the other's position to the satisfaction of the other (Burton 1969). Again, it is not necessary to agree with the position of the other, merely to clarify. This in itself helps to build understanding and roll back misperceptions.

In the final step, given this new understanding, rather than focusing on how to achieve our own goals, we consider whether there are other ways in which we can ensure the substantive interests (not positions) of the other party, with the aim of a more lasting settlement and maintenance of a long-term cooperative relationship. Both Fisher and Burton advise us to deconstruct the nature of the conflict itself and the identity of the participants in order to work towards a lasting peaceful relationship. Fisher, Ury, and Patton $(1991,17)$ advocate that we "separate the people from the problem" in order to reduce hostility and encourage the notion of negotiators as joint problem-solvers rather than opponents.

Negotiations take place in the context of long-term relationships and through communication. The negotiating sessions themselves are the venue for communication. Without effective two-way communication, negotiators would have limited knowledge about the other side's concerns, interests, and preferences on the negotiating agenda. On the other hand, negotiators can improve their mutual gains through exploring their interests. Meanwhile, it is also important to keep in mind Burton's conclusion that people most commonly come into conflict because they feel that their identity is not being recognized, that they are not being treated with the dignity and respect due them as individual human beings and the bearers of rights and needs (Burton 1990b); this is true even when the conflict appears to be about something much more material such as land or resources. The next section looks at conflictual case studies where such approaches have been used. 


\section{Peacebuilding and Reconciliation Case Studies}

This section analyzes a number of seemingly intractable conflictual situations drawn from the history of international diplomacy and the author's own practical experiences in the field, where the processes of reconciliation and relationship transformation were faced with similar challenges to those found in the Northeast Asian operating environment. In each case some of the theoretical steps advocated by the Fisher School and John Burton were put into action, and at least held some promise of ameliorating the situation.

\section{Land for Peace: The Sinai}

The conflictual relationship between Israel and Arab nations has been perceived as perhaps the most intractable in the contemporary strategic operating environment. Essentially this is because it is often viewed as zero-sum, with both sides laying claim to the same territory, committing gross violations of human rights, denying the other's right to exist and thereby posing an existential threat to the other. There have, however, been moments of reconciliation. These occurred when processes similar to those advocated by Fisher and Burton have been put into practice. This was the basis of the historic "land for peace" approach to the conflict between the Israelis and Egyptians (and later other Arab peoples) that has come closer than any other process to ensuring peace in the Middle East. The land for peace formula appeared for the first time in UN Security Council Resolution 242 in 1967 in the aftermath of the Six Day War, and was first used as the basis for Israel's peace treaty with Egypt in 1979. The initial military conflict had left the Sinai Peninsula in Israeli hands. Over the following four years (196770) a limited war of attrition was waged between Egypt and Israel over possession of the territory, resulting in some one million internally displaced persons (IDPs) in Egypt. In 1973 Egypt launched major military operations as part of the Yom Kippur War aimed at recapturing Sinai. In this they were unsuccessful.

As a result of the 1979 Camp David Peace Accords between the two countries, Israel withdrew from the Peninsula. Reconciliation achieved what had proven impossible through force of arms. The process for this transformation involved recognition that while the positions of both sides were that military occupation of the Peninsula was of vital importance to national security, this was not in fact wherein lay the interests of either side. For Egypt, vital national interest involved reunification with the homeland of territory which had been Egyptian for millennia. For Israel it lay in not having Egyptian forces so close to the Israeli border given repeated attacks from that quarter. By returning the Sinai to Egyptian control, but limiting the presence of Egyptian forces, both interests were fulfilled. In addition, there were mutual gains in terms of peace, including Israeli tourism to Sinai.

A key role was played by Boutros Boutros-Ghali, Egypt's Foreign Minister 
under President Anwar Sadat. He accompanied Sadat on his historic trip to Jerusalem in 1977, and was an architect of the Camp David Accords which led to the Egypt-Israel peace treaty of 1979 (BBC 2016). As a minority Coptic Christian married into a Jewish family, in a predominantly Muslim country recently at war with Israel, it is perhaps not surprising that Boutros-Ghali was able to look beyond state-centric political power positioning, and consider instead the shared interests of the peoples of the Middle East. He was able to separate the people from the problems, and also to address the assumptions of his own side in the negotiations at Camp David. Later, as Secretary General of the United Nations, he was to continue to champion peace and the rights of peoples, even at the expense of so-called national interest (Boutros-Ghali 1992).

\section{Land for Peace: The Oslo Accords}

Land for peace aims at fulfilling some of the desires of others, thereby reducing the hostility and level of threat they in turn pose to you. This then is a key element of transforming a conflictual relationship by tackling mutually exclusive positions and uncovering shared and complementary interests. Thus one category of challenges listed in the introduction and theoretical analysis sections, that of positional obstacles, was successfully overcome by the land for peace negotiation process. The perceptional challenges listed above have also been tackled, however, by more recent incarnations.

The principle reappeared in the peace agreement, or Oslo Accords, between Israel and representatives of the Palestinian Liberation Organization (PLO) finalized in Oslo, Norway on August 20, 1993, according to which the Israelis would hand over most of the territories they had formerly occupied, which were to form the foundations of a future Palestinian state. In return relations were to be normalized, terrorist attacks upon Israel were to cease, and each side pledged recognition of the other. Thus again positions were sacrificed in order to secure interests and mutual gains. However, the Accords also essentially constituted a real-world attempt at a Burtonian problem-solving workshop. They were the result of secret negotiations between representatives of Israel and the PLO, about which nothing was released to the media until agreement had been secured from both parties. Both sides had to abandon their partisan perceptions and accept the right of the "other" not only to exist, but also to engage in negotiations as representatives of their respective peoples before such engagement could even begin. This mutual legitimization and recognition helped transform the conflictual relationship.

Although, as is clear from the continuation of hostilities, the process is far from complete, any failure has in all probability been due to the lack of recognition of the decision-making complexities of the parties involved rather than limitations of the Assumption/Data Tool, the problem solving workshop, or the basic formula of land for peace. Fisher, Ury, and Patton (1991, 37) advocate 
that mutual gains not be left on the table, yet at the time of the breakthrough in negotiations final resolution on knotty problems such as the ultimate status of the Palestinian political entity, the borders of Israel and Palestine, the Israeli settlements, the status of Jerusalem, the question of Israel's military presence in and control over the remaining territories after the recognition of Palestinian autonomy by Israel, and the Palestinian right of return, were left behind.

Furthermore, Burton had advocated the inclusion in talks of all interested parties who have the capacity to affect the outcome of a peace process. In particular it is important to involve extremists, as they are likely to be most successful in selling any agreement back to domestic constituencies (the problem of re-entry). The Oslo Accords only involved moderates on both sides. As a result, on the Palestinian side the relatively moderate Palestinian Liberation Organization faction of Fatah was outmaneuvered by the much more radical Hamas organization which opposed the peace process. Meanwhile, Israeli Prime Minister Yitzhak Rabin was assassinated in 1995 by a Jewish radical at the end of a peace rally in Tel Aviv.

\section{Nagaland}

In Nagaland, in the northeast of India, indigenous groups have been waging a low-intensity ethnic separatist insurgency for more than 60 years. As became clear during a visit by the author (in January 2013) to run a Burtonian problemsolving workshop with representatives of both sides to the conflict as well as civil society groups, the position of the rebels was that nothing short of independence was acceptable. Their perception of the Indian government was that the authorities were merely bent on stripping the Northeastern states (Nagaland and also Manipur, Assam and Arunachal Pradesh, where significant numbers of Naga live) of their resources and redirecting profits to New Delhi. They saw the New Delhi authorities as patronizing, neocolonial, and even racist. For the Indian government, concessions were seen as dangerous since they could not risk encouraging other separatist movements in such a large, heterogeneous country. A breakthrough only became possible when all sides started to shift from positional bargaining to interest-based negotiations, and to efforts to understand and respect the position of the "other."

Although the peace treaty with the largest faction of Naga insurgents has only freshly been signed (August 2015), with details of the transition still sketchy, nevertheless it seems that both sides have shifted in their positions, the better to fulfill their interests. There has also been a clear shift in the perceptions of the "other" for both sides, and this has been reflected in their language use. The rebels appear no longer to be calling for complete secession, but rather for the development of local resources in the interests of the local communities, and recognition of greater community rights (BBC 2015b). At the same time, Indian Prime Minister Narendra Modi described the accord between his government 
and the National Socialist Council of Nagaland as "historic," noting that he had "the deepest admiration for the great Naga people for their extraordinary support to the peace efforts" and expressing the hope that the resolution of the country's oldest insurgency was a signal to other groups to give up their weapons (BBC 2015a). Thuingaleng Muivah, the chief of the main rebel group, the National Socialist Council of Nagaland (NSCN), thanked Indian Prime Minister Narendra Modi for "understanding the problems faced by the Nagas," while Mr. Modi acknowledged that the problem festered so long because India and the Nagas failed to "understand each other" (BBC 2015b).

\section{The Northern Ireland Peace Process}

The conflict surrounding Northern Ireland was, for a long time, seen to be every bit as intractable as those in the Middle East or Northeast Asia. There was a territorial zero-sum game with Northern Ireland being viewed as part of the United Kingdom (UK) by one community in the province and its international supporters; and being viewed as part of an unjustly divided Irish state entity by the other community and its supporters. There were also most certainly competing regimes of the truth, with each community championing its own foundational myth, perpetually reinvigorating and reinventing its history of struggle against an intractable foe blamed for all of society's evils and suffering, and claiming that the "other" posed an existential threat. The conflict was further exacerbated by religious, linguistic, ethnic, and socio-economic divides between the two communities. The long-running conflict-essentially a civil war which spilled over into Britain, the Irish Republic, mainland Europe, and even North America-was euphemistically referred to as "the troubles."

As the administering power, the UK tried a number of state-centric solutions, including partition of conflictual neighborhoods, the deployment of troops, and judicial solutions of dubious legality, as well as state-to-state negotiations with the Irish Republic. All these measures were, however, doomed to fail, until the governments of Ireland and the UK brought all the major actors, including nonstate actors as diverse as political parties, civil society organizations, and even terrorists, into the problem-solving approach, as of course Burton would have advocated.

Ultimately the process of engagement with all the parties culminated in the Good Friday Agreement, two interrelated documents, signed in Belfast on Good Friday, April 10, 1998. These documents were a multi-party agreement to which most of Northern Ireland's political parties had signed up, and an international agreement between the British and Irish governments (the BritishIrish Agreement), which together required action by all the stakeholders, national governments, local political parties, civil society, and terrorist groups on both sides of the sectarian divide. The interests of all these parties were addressed. Strand 1 contained provisions relating to the status and system of government 
of Northern Ireland within the UK. Strand 2 addressed the relationship between Northern Ireland and the Republic of Ireland. Strand 3 reflected on the relationship between the Republic of Ireland and the UK. Many of the underlying grievances and interests of parties were addressed by provisions relating to civil and cultural rights, decommissioning of weapons, justice, and policing.

Although the Agreement was no panacea, and there have been both breakdowns of governance in Northern Ireland and some isolated ceasefire violations, the success of the peace process in transforming conflictual relationships can be measured by the overwhelming support for it both during the Agreement ratification process and since. The Agreement was approved by voters in both the North and South of the island of Ireland in two referendums held on May 22, 1998. In Northern Ireland, voters were asked whether they supported the multi-party agreement. In the Republic of Ireland, voters were asked whether they would allow the state to sign the agreement and allow necessary constitutional changes to facilitate it. Both referendums received very significant "yes" votes. The process also brought the communities into contact as joint problem solvers rather than adversaries, and facilitated recognition of the interests, needs, and fears of the "other" rather than their demonization. Again, the people were separated from the problems, and misperceptions corrected. These days the province has been transformed almost beyond recognition, and despite ongoing socio-economic and governance challenges, the people of Northern Ireland count themselves the happiest in the UK (Independent 2015).

\section{The Korean Peninsula}

Finally, in a case study closer to home in terms of both geography and chronology, the recent (August 2015) inter-Korean crisis on the Peninsula offers valuable insights as to the dangers of playing the traditional blame game, but also points to the benefits of a negotiated agreement on language to be used in a reconciliation report. On August 9, 2015, two South Korean soldiers were wounded after stepping on landmines that had allegedly been laid by North Korean forces next to a ROK guard post on the southern side of the Demilitarized Zone (DMZ). South Korea responded by restarting propaganda broadcasts from loudspeakers at the DMZ, a practice that both sides had previously agreed to discontinue. On August 20, North Korea fired a single $14.5 \mathrm{~mm}$ anti-aircraft shell at the offending speakers. South Korea responded by firing multiple shells from a $155 \mathrm{~mm}$ direct fire weapon.

North Korea, of course, has a long history of brinksmanship, and of prioritizing national security, even to the extent of adopting an official "military first," or Seon'gun, policy platform. Actions such as restarting its nuclear program, testing nuclear devices and missiles, and in 2010, sinking the South Korean naval corvette Cheonan, and shelling the South Korean island Yeonpyeong near the Northern Limit Line (NLL) have heightened the trepidation of near neighbors 
and the wider international community. It is not necessarily the increasing strength of North Korea that threatens, however, but rather Pyongyang's increasing weakness; an "insecurity dilemma" rather than a security dilemma, where in addition to posing a threat to its own people, the insecure state's vulnerability is projected outwards as a diversionary and unifying tactic causing international uncertainty and instability as well as security threats to neighboring states. Diversionary international crises and conflict generation, in fact, has a lengthy pedigree, particularly among authoritarian regimes. Other well-known incidents include Indonesia's military confrontation (konfrontasi) with Malaysia in 1963 when President Sukarno's political control and power were waning, and the decision by the military junta of Argentina to invade the UK-administered Falkland Islands in 1982.

In the most recent crisis, however, it seems that democratic South Korea may have had as much, or maybe even more, interest in escalating matters. There are a number of important critiques which can be made regarding the sequence of events. First, landmines along the DMZ are subject to spontaneous movement due to thin soil and adverse weather conditions, and it is by no means certain when and where these mines were laid. Second, South Korea's responses may not have been proportionate: restarting a propaganda mechanism which had previously contributed to the escalation of tensions on the Peninsula, violating one of the few agreements between the two sides which up to that point had actually held up, and responding to a single small caliber shot with multiple rounds of a much larger caliber. Third the diversion of public attention towards the deteriorating situation at the DMZ came at a time when reports were due on alleged electoral manipulation by the governing party and the National Intelligence Service.

Thus both sides could be accused of putting regime and/or national security considerations before the wellbeing of their citizens. On the other hand, a significant positive can be taken from the way the crisis was ultimately defused. In the final wording of the joint statement released by the two Koreas after a mammoth crisis summit meeting, North Korea expressed "regret" for what had happened to the South Korean soldiers. This stopped short of the apology originally demanded by South Korea, but at least acknowledged suffering and hurt. Importantly, it did not explicitly attribute blame. Thus both sides could find the space to back down from the confrontation with dignity. Indeed, the wording of the document was such that both sides could claim victory on behalf of their constituents.

Of course this is not to imply that the resolution of this particular issue has brought ultimate reconciliation on the Korean Peninsula significantly closer. What the meeting did demonstrate, however, was what is possible when two adversaries meet to address a problem and find a negotiated agreement which at least addresses the vital interests of both sides tolerably well. Furthermore, by 
taking this first step, other confidence-building and socialization measures, such as family reunions, may be relaunched with more optimism. Hopefully such measures will ultimately lead to a perceptional shift.

\section{Lessons and Prescriptions for Northeast Asia}

As detailed above, all countries in Northeast Asia have a self-perception of victimization by others and an ongoing belief that others pose an existential threat. Any proposal for future initiatives aimed at providing reconciliation and securing a lasting peace must address these perceptions. The first step towards this is to acknowledge that all communities have indeed been hurt, and to that extent are victims, without taking the antagonistic step of placing blame. Indeed, all the peoples of Northeast Asia have been victimized by both domestic and foreign agents of oppression.

This fact may, ironically, facilitate reconciliation for a number of reasons. First, the awareness of shared experience facilitates mutual understanding and the growth of empathy. Second, in terms of collective problem-solving rather than positional negotiations, this approach constructs domestic and foreign oppression and violation of human rights as a common challenge and enemy against which all the countries of the region can unite. Third, in combining all the sources of suffering in the region, the adversarial and blame-focused examination of each individual instance is diluted, while its humanitarian imperative remains in force.

As demonstrated in the above analysis, it is vital to separate the people from the problems, but also to distinguish between real interests and mere strategic positions. These objectives become more achievable through confidencebuilding, communication, and ultimately the construction of good relationships between the peoples of Northeast Asia. A major component of such processes is to hand the initiative to non-state, trans-state, or sub-state actors, as state-tostate engagement is inherently positional, and the interests primarily defended are those of national security and prestige rather than wellbeing, reconciliation, relationship transformation, and healing. Furthermore, state actors are more likely to be irrecoverably entrapped by sunk costs, and constrained by the operational straight-jackets of standard operating procedures. Thus diplomatic negotiations may be suitable for conflict management, or even resolution, but not for the transformation of underlying conflictual relationships. It is difficult for any state-level actor to engage in the degree of out-of-the-box thinking required.

Indeed, one trend in contemporary diplomatic theory and practice does emphasize such non-traditional thinking. Public diplomacy has grown in stature among a number of key states in the international system, including in South Korean diplomatic circles. Thus for Nicholas Cull, "the significance of publics in foreign policy may be the defining characteristic of foreign policy in our age" 
(2013, 17). Likewise, for Paul Sharp, "public diplomacy, the process by which direct relations are pursued with a country's people to advance the interests and extend the values of those being represented, appears to be an idea whose time has come" $(2005,106)$.

The Republic of Korea, has been a somewhat late convert to the concept, officially endorsing it only in 2010 (Ma, Song, and Moore 2012). Yet Korea has become, in a relatively short space of time, an enthusiastic contributor to the discourse and a proponent of related policy initiatives (Cull 2013, 19). The national government of South Korea has primarily employed a limited statecentric interpretation of public diplomacy whereby the national state apparatus focuses on projecting a good image of the country in order to influence external public opinion. As such it has much in common with the concept of soft power, and indeed, the government of the Republic of Korea uses the terms pretty much interchangeably (Huh 2012).

There are, however, unfortunate connotations with soft power terminology and usage, and with the state-centricity of these interpretations. "Power" itself can be seen to have negative or even pejorative connotations, and concerns remain that when directly wielded by the representatives of a state, there can be significant blurring of the boundaries between soft power and hard power. Although it can clearly be wielded by non-state actors, as mentioned above, and used to target the populations of other countries, soft power also seems to follow traditional diplomatic and strategic models of interaction, viewing actors as unitary and rational. There is always a danger that the overt pursuit of public diplomacy and soft power comes off as, at best, unsubtle propaganda, and at worst, as meddling in the internal affairs of partner states.

If public diplomacy is seen simply as a way for states and statesmen strategically to target the populations of other countries, it is unlikely to get much further than attempts to "win hearts and minds," or simply being labelled government "spin." "Winning" implies psychological operations aimed at manipulating or even coercing the public of a target state in a manner almost as controversial as hard power operations, and is just as likely to generate a negative backlash by those who feel they are being manipulated. Thus, even if the nomenclature plays well with politicians and domestic publics, there are strategic problems with the current emphasis of the government of Korea on the use of public diplomacy as an element soft power, or as a way of winning the hearts and minds of overseas publics.

Even the use of the term "public diplomacy" by official organs of a state can be problematic, as it comes with all the baggage attached to other forms of diplomacy. That is to say, it is an overt attempt to project the interests of the state. Recent developments in the discourse, therefore, reject too great a linkage between public diplomacy and national power projection. For Alan Henrikson, the assimilation of publicly-conducted diplomacy to soft power is a conceptual 
mistake, and far too reductionist, because a diplomacy that is expected to have public appeal and to win favor for a country must rely on the moral, political, and intellectual assent of the populations addressed by it. "Most publics cannot be entirely won over - either coerced or co-opted - by intimations of power, however subliminal or politely veiled" (Henrikson 2005, 68).

Non-state actors, therefore, are key players in the creation of nonthreatening public diplomacy. Indeed, public-to-public diplomacy rather than state-to-public diplomacy is called for in order to facilitate the processes of conflict transformation and reconciliation. That being said, in order to create the requisite shared body of knowledge and commitment, one party needs to provide leadership, but also to remain as impartial as possible. Previous attempts, despite good intentions, have tended to degenerate into using historical narratives to justify contemporary positions on territorial disputes, or to place blame for historical wrongs. Here we could learn from Burton's approach, and invite academic representatives from all the countries in the region to a workshop to address the issues of human suffering, and to identify the historical period on which the project will focus its energies (starting as early as the late $19^{\text {th }}$ century, potentially ending as late as the contemporary operating environment).

After the initial academic meeting to address the parameters of the investigation and acknowledgement of hurt, the project could be expanded in three directions: first, continuation of the academic project resulting in the publication of a universally agreed textbook; second, continuation of discussions by political and bureaucratic entities resulting in a joint declaration on human security in the region, acknowledging the dismal catalogue of human suffering while all sides pledge never to allow such things to happen again; and third, engagement of civil societies in each country, in particular the youth, in events aimed at breaking down barriers, facilitating understanding, and promoting reconciliation.

On the academic front, by addressing both domestic and foreign gross violations of human rights during the agreed timeframe, a larger degree of hurt can be acknowledged, while a greater degree of distance from blame can be maintained. A common textbook would, therefore, include the suffering of the ordinary Japanese citizens at the hands of American, Russian, and Japanese forces and administrations, without pointing fingers at those who may generally be considered to blame. Korean hurt would be acknowledged in terms of the suffering under colonialization, during World War II (including comfort women, slave labor, conscription, etc.), as a result of the division of the Peninsula, and under domestic authoritarian regimes. The suffering of the Chinese people under the aegis of European and Japanese imperialism, during civil and international wars, and as the result of historic mismanagement could also be addressed.

A further Burtonian progression would be to require humanitarian tragedies in each country to be addressed by academics other than those from that country. 
Hence, a Japanese academic would write about South Korean suffering in the agreed timeframe, a Chinese academic would write about Japanese suffering, and a South Korean would write about Chinese suffering. This could be expanded to include North Korea and Taiwan. This is, of course, a very different proposal from the national unified history textbook projects launched throughout the region, but most prominently, and recently, in Japan and South Korea, in which policy makers attempt to rewrite a historical narrative. These controversial efforts are the exact opposite of the process proposed here.

On the policy front, again learning from the Burtonian approach, a track two or track three institution could hold a series of workshops for policy makers. The talks would be kept confidential with nothing listed as agreed until everything had been agreed. This gives a further incentive for making concessions. These workshops should not begin with a detailed agenda, but should rather be described and run as research seminars that have an open agenda to be shaped by the participants. Likely topics to be addressed, however, would include the origins of conflict in the region, its underlying issues, and obstacles to resolution, as well as matters of trust, how to reduce tension, and what confidence-building measures or de-escalation tactics would be effective (Maisse 2003).

In the second stage of problem solving, each party will ultimately, as detailed above, have to explain the position of the other to the other's satisfaction. Thus, at this point, panelists should try to provide some bridge into this second and more productive stage of the workshop. It is at this point that Fisheresque "active listening" takes place-with participants asking of each other why they feel the way they do about certain issues-until sufficient comprehension is generated of opposing views, and the reasoning behind them, to allow representation of another participant's position to their satisfaction. Interests are separated from positions, and people are separated from problems, in order to allow the various sides to come together to address the conflicts as problems which must be jointly addressed through collaborative efforts rather than as adversarial problems. The parties are invited to explore the central issues of their conflict and search for solutions that do not require any of the parties to compromise their basic interests or needs. Appealing to "solutions" that the various participants identified in earlier statements, facilitators lead the discussion and explore various possibilities for ending the conflict in question. This is the process of option generation identified by the Harvard Negotiation Project.

By this time, if nothing more, the participants will have developed a strong understanding of what the obstacles to resolution are, and should emerge from the workshop with the feeling that they have a deeper understanding of their conflict and some ideas about moving toward resolution. They should recognize that continued problem-solving, confidence-building, negotiating, and relationship-building endeavors are much more persuasive than their best alternatives to a negotiated agreement (BATNAs). Because a single workshop 
is unlikely to include all the relevant parties or deal with all the issues, a series of meetings may be necessary. But even a single workshop can create new opportunities for communication between groups of antagonists.

Depending on the level of the participants, the eventual end product could be a joint declaration of heads of cities, provinces, or governments expressing a commitment to defend the human security of their populations against all who may threaten it. At the very least, the experience of these negotiations, combined with the active listening they will require, should serve to de-escalate hostile rhetoric. The most important task faced by the facilitators is to listen to the parties and analyze the nature of the issues in conflict as well as the obstacles to resolution. "Because the central issues often go beyond those portrayed in the parties' public positions, consultants must listen for hidden agendas and unacknowledged resentments" (Maisse 2003).

On the civil society front, educational youth-based projects involving student exchange, visits to commemorative sites, youth conferences, simulation exercises and debate competitions, as well as pairing students from different countries to produce joint reports, could all greatly contribute to a de-escalation of nationalism and hostility among the younger generations. Student (and perhaps faculty) exchanges within the region could constitute an important avenue of civil society interaction. Ultimately, an education program which sees students spend semesters in each of the countries of Northeast Asia would make a tremendously beneficial contribution to reconciliation and the transformation of conflictual relationships. This would follow a similar sort of structure to the European Erasmus programs wherein students study at least three months or do an internship for a period of at least two months to an academic year in another European country. Less ambitiously, civil society and local governmental actors could sponsor youth exchange and interaction programs in sport, debating, Model UN, Model APEC, etc.

The aim of all of these programs is to facilitate communication, foster understanding, decrease xenophobia, and contribute to confidence building leading to the generation of a cooperative culture among the region's future leaders. Any one, or all of these project and tracks could be pursued after the hosting of the initial, foundational workshop, in collaboration with academic research institutes at some of the top regional universities. While the costs involved would be fairly limited, the ultimate contributions are substantial.

\section{Conclusion}

Northeast Asian conflicts have been seen as among the most intractable in the world. Conflicting perceptions and regimes of the truth combine with positional negotiating postures and the primacy of the state in regional security and foreign 
policy-making. Yet a wide body of literature, as well as a growing number of real-world cases have revealed methodologies for unpacking the "black box of decision," understanding the "other," deconstructing the relationship between positions and interests, and increasing the role played by non-state and sub-state actors. These include negotiation and problem solving workshops engaging in active listening, use of assumption/data tools, and a focus on communication and relationship building.

This paper has analyzed systematically potential policy prescription for steps which may be taken to break the vicious cycle of hurt, blame, and rising nationalism in the region. These include that a truly "public" take on public diplomacy should be the diplomacy of the publics, not the exercise of "soft" power by state actors in order to exert influence over others, and that a Burtonian problem-solving approach could lead to workshops and ultimately joint output in the academic, policy, and civil society communities. While none of these measures is viewed as a panacea for the region's problems, especially given the entrenched resistance of policy elites, they all represent the kind of "out-ofthe-box" thinking, and out of the "black box" foreign policy analysis, required to break the current deadlock. At a minimum, their inclusiveness should stimulate communication and hence lead to better understanding and ultimately relationship building, and even the transformation of conflictual relationships.

\section{Notes}

The author would like to thank the anonymous reviewers of the Asian Journal of Peacebuilding for their constructive comments. The article draws on work commissioned by the Seoul Institute for the Seoul Metropolitan Government, and is reproduced here by their permission.

\section{References}

Acharya, Amitav. 2003. "Guns and Butter: Why do Human Security and Traditional Security Co-exist in Asia?" Global Economic Review: Perspectives on East Asian Economies and Industries 32 (3): 1-21.

Allison, Graham. 1971. Essence of Decision. Boston: Little, Brown and Company.

Braybrooke, David and Charles E. Lindblom. 1969. A Strategy of Decision: Policy Evaluation as a Social Process. New York: Free Press.

BBC. 2015a. "India Signs Peace Accord with Naga Rebels." August 3. http://www.bbc.com/ news/world-asia-india-33762445 (accessed May 5, 2016).

BBC. 2015b. "Will India’s Peace Deal with Naga Rebels Work?” August 4. http://www.bbc. com/news/world-asia-india-33769476 (accessed May 5, 2016).

BBC. 2016. “Obituary: Boutros Boutros-Ghali.” February 17. http://www.bbc.com/news/ 
world-middle-east-12540418 (accessed May 5, 2016).

Boutros-Ghali, Boutros. 1992. An Agenda for Peace: Preventive Diplomacy, Peacemaking and Peace-keeping. http://www.un.org/documents/ga/res/47/a47r120.htm (accessed May 5, 2016).

Burton, John W. 1969. Conflict and Communication. London: Macmillan.

Burton, John W. 1990a. Conflict: Resolution and Prevention. New York: St. Martins Press.

Burton, John W. 1990b. Conflict: Human Needs Theory. New York: St. Martins Press.

Chu, Shulong. 2001. "China, Asia and Issues of Sovereignty and Intervention," Pugwash Occasional Papers, 2 (1).

Cull, Nicholas. 2013. “Issue Brief: 'Building Ideas': Making Korean Public Diplomacy Work.” Public Diplomacy Magazine Summer 2013. http://publicdiplomacymagazine. com/issue-brief-bulging-ideas-making-korean-public-diplomacy-work/ (accessed May 5, 2016).

Deutsch, Karl W. 1978. The Analysis of International Relations, $2^{\text {nd }}$ ed. New Jersey: PrenticeHall.

Fisher, Roger, William Ury, and Bruce Patton. 1991. Getting to Yes. New York: Penguin.

Fisher, Roger, Andrea Kupfer Schneider, Elizabeth Bogwardt, and Brian Ganson. 1997. Coping with International Conflict. New Jersey: Prentice-Hall.

Henrikson, Alan. 2005. "Niche Diplomacy in the World Public Arena: the Global 'Corners' of Canada and Norway." The New Public Diplomacy: Soft Power in International Relations. Jan Melissen ed. Basingstoke: Palgrave Macmillan.

Holsti, Kal J. 1991. Peace and War: Armed Conflicts and International Order 1648-1989. Cambridge: Cambridge University Press.

Huh, Tae-Wan. 2012. “The Republic of Korea's Public Diplomacy as a Policy Tool of Soft Power." The Future of Public Diplomacy 3(2). https://uscpublicdiplomacy.org/pdin monitor_article/republic-korea\%E2\%80\%99s-public-diplomacy-policy-tool-softpower (accessed May 5, 2016).

Independent (The). 2015. “The UK's Happiest Places have been Revealed." September 25. http://www.independent.co.uk/news/uk/home-news/the-uks-happiest-places-havebeen-revealed-10515924.html (accessed May 5, 2016).

Jervis, Robert. 1969. “Hypothesis on Misperception.” In International Politics and Foreign Policy: A Reader in Research and Theory, ed. James Rosenau. New York: The Free Press.

Jervis, Robert. 1976. Perception and Misperceptions in International Politics. Princeton, NJ: Princeton University Press.

Thomas S. Kuhn. 1962. The Structure of Scientific Revolutions. Chicago: University of Chicago Press.

Ma, Young Sam, Jung-he Song, and Dewey E. Moore. 2012. "Korea’s Public Diplomacy: A New Initiative for the Future." Asan Policy Institute Issue Brief 39. http://en.asaninst. org/contents/issue-brief-no-39-koreas-public-diplomacy-a-new-initiative-for-thefuture/ (accessed May 5, 2016).

Maisse, Michelle. 2003. "Problem Solving Workshops." Beyond Intractability. http://www. beyondintractability.org/essay/problem-solving-workshops (accessed May 5, 2016).

Putnam, Robert. 1988. "Diplomacy and Domestic Politics: The Logic of Two-Level Games." International Organization 42: 427-460.

Sharp, Paul. 2005. "Revolutionary States, Outlaw Regimes and the Techniques of Public 
Diplomacy." In The New Public Diplomacy: Soft Power in International Relations, ed. Jan Melissen. Basingstoke: Palgrave Macmillan.

Simon, Herbert A. 1956. "Rational Choice and the Structure of the Environment." Psychological Review 63 (2): 129-138.

Simon, Herbert A. 1957. Models of Man: Social and Rational. New York: Wiley.

Simon, Herbert A. 1991. "Bounded Rationality and Organizational Learning." Organization Science 2 (1): 125-134.

Brendan M. Howe is a Professor and former Department Chair of the Graduate School of International Studies, Ewha Womans University, where he has worked since 2001. His ongoing research agendas focus on traditional and non-traditional security in East Asia, human security, democratic governance, public diplomacy, and post-crisis development. Major recent works include Democratic Governance in Northeast Asia (2015); Post-Conflict Development in East Asia (2014); The Protection and Promotion of Human Security in East Asia (2013); and Northeast Asian Perspectives on the Legality and Legitimacy of the Use of Force (2013). E-mail: howeb@ewha.ac.kr; bmg.howe@gmail. com 
